\title{
Pengaruh Pembelajaran Daring (BDR) Terhadap Perkembangan Sosial Anak Pada Masa Pandemi Di Taman Kanak-kanak
}

\author{
Nela Yunita ${ }^{1}$, Dadan Suryana ${ }^{2}$ \\ Universitas Negeri Padang, Universitas Negeri Padang \\ * e-mail: yunitanela1@gmail.com, suryana@fip.unp.ac.id
}

\begin{abstract}
This study aims to examine the effect of BDR online learning on the social development of children at the Bunga Harapan Bunga Pasang Kindergarten. This type of research is a quantitative research using a questionnaire distributed to parents/guardians of students. The population in this study were children and their parents in the beam center group of 8 people, the imtaq center 8 people and the arts center 8 people. So the number of samples used is as many as 24 parents / guardians of students. The data collection technique is a questionnaire. The data analysis technique used the formula Ttable and Fcount which was analyzed using IMB SPSS 26. Based on the data analysis, the correlation coefficient of BDR online learning on social development hypothesis Tcount $>T \mid$ table (2.497> 2.074) and $F$ test where Fcount>Ftable (6,253> 1,711). This means that there is a significant effect of BDR online learning on the social development of children at the Bunga Harapan Bunga Pasang Kindergarten
\end{abstract}

Keywords: Pembelajaran Daring BDR, Perkembangan Sosial

\section{PENDAHULUAN}

Usia dini adalah periode awal yang penting serta mendasar dalam dalam sepanjang rentang pertumbuhan dan perkembangan pada kehidupan manusia. Pada masa ini ditandai dengan berbagai periode penting yang fundamental dalam kehidupan anak selanjutnya sampai periode akhir perkembangannya. Banyak konsep dan fakta ditemukan bahwa ditemukan penjelesan periode keemasan pada anak usia dini dimana semua pontensi anak berkembang paling pesat Suryana (2021). Salah satu periode yang menjadi ciri masa usia dini adalah periode keemasan Anak usia dini ditujukan kepada anak yang berusia 0 sampai 6 tahun. Dalam proses pendidikannya, biasanya dapat dikelompokkan menjadi beberapa tahapan berdasarkan golongan 
usia. Misalnya untuk usia 2-3 tahun masuk pada kelompok Taman Penitipan Anak (TPA), usia 3 4 Tahun masuk kelompok bermain (KB), dan 4-6 tahun untuk Taman Kanak-Kanak (TK). Menurut Yaswinda,dkk (2018) menjelaskan bahwa pendidikan anak usia dini merupakan pendidikan yang diberkan kepada anak mulai dari lahir hingga berusia delapan tahun bertujuan untuk membentuk kepribadian manusia secara utuh yang kepribadian tersebut terdiri dari karakter, budi pekerti luhur, cerdas, dan terampil. Menurut Suryana (2013) adapun karaktersitik anak usia dini adalah: 1) Anak bersifat egosentris, 2) Anak memiliki rasa penasaran yang tinggi, 3)Anak bersifat unik 4) Anak kaya imajinasi dan fantasi, 5) Anak memiliki jiwa konsentrasi yang pendek. Musyarofah (2017) Perkembangan sosial adalah pencapaian kematangan dalam hubungan sosial. Dapat diartikan sebagai proses belajar untuk menyesuaikan diri pada norma-norma kelompok, moral, serta tradisi, meleburkan diri menjadi satu kesatuan dan saling berkomunikasi dan bekerjasama. Perkembangan sosial anak dapat dipengaruhi pada proses perlakuan atau bimbingan pada orangtua di keluarga serta tenaga kependidikan lain disekolah dalam mengenalkan aspekaspek kehidupan sosialnya, serta norma-norma kehidupan bermasyarakat atau mendorong dan memberikan contoh kepada anak bagaimana menerapkan norma tersebut. Suryana (2016) mengemukakan faktor-faktor yang mempengaruhi perkembangan sosial anak usia dini diantara nya yaitu: 1) keluarga, adalah lingkungan utama yang memberikan pengaruh besar terhadap berbagai aspek perkembangan anak, termasuk perkembangan sosial nya, 2) kematangan, untuk dapat bersosialisasi dengan baik diperlukan kematangan fisik dan psikis, 3) status sosial ekonomi, kehidupan sosial banyak dipengaruhi oleh kondisi sosial ekonomi keluarga dalam masyarakat, 4) pendidikan, yaitu proses sosialisasi pada anak yang terarah, 5) kapasitas mental, emosi dan intelegensi yaitu kemampuan berfikir dapat mempengaruhi seperti kemampuan belajar, memecahkan masalah, dan berbahasa.

Kurniasari dkk (2020) Kegiatan Belajar dari Rumah (BDR) ini adalah peserta didik dapat mengakses materi dan sumber pembelajaran tanpa batasan waktu dan tempat. Proses pembelajaran yang biasanya dilaksanakan di sekolah dengan tatap muka langsung dengan bapak/ibu guru dan 
teman-teman tidak dapat dilakukan pada masa pandemi ini. Para siswa diharuskan belajar dari rumah (BDR), untuk itu guru juga diharuskan menyiapkan perangkat pembelajaran yang memungkinkan siswa untuk belajar dari rumah. Kondisi ini membuat guru harus mengubah strategi belajar mengajarnya. Penggunaan metode pengajaran yang tepat maupun perilaku dan sikap guru dalam mengelola proses belajar mengajar sangat dibutuhkan dalam pembelajaran selama program belajar dari rumah (BDR). Semua ini dilakukan untuk memberikan akses pembelajaran yang tidak terbatas ruang dan waktu kepada peserta didik selama diberlakukannya masa darurat Covid-19.memberikan contoh kepada anak bagaimana menerapkan norma tersebut. Pengertian pandemi menurut Kamus Besar Bahasa Indonesia (KBBI) dalam Ristyawati (2020) merupakan wabah yang berjangkit serempak di mana-mana atau meliputi geografi yang luas. Kasus ini muncul bermula terjadi di Wuhan, Tiongkok dan mulai menyebar ke hampir seluruh dunia. Penyebaran COVID-19 ini sangat cepat dan tidak ada yang mampu memprediksi kapan berakhirnya pandemi COVID-19 ini. Kasus Covid-19 yang merupakan pandemi global jelas menimbulkan kekhawatiran dari beragam kalangan, khususnya masyarakat.

Dapat diliat dari keadaan sekarang ini dimana anak-anak belajar dirumah menggunakan whatsapp dan LKA yang mana anak-anak tidak dapat berinteraksi dengan teman sebaya nya dengan itu dapat menghambat perkembangan sosial anak karena anak yang jarang bertemu dengan teman-teman sekolah nya.

\section{METODE}

Penelitian ini menggunakan pendekatan kuantitatif dengan menggunakan angket menurut. Widyoko dalam Purnomo (2016) Angket merupakan teknik pengumpulan data dengan cara memberikan seperangkat pertanyaan tertulis kepada reponden sesuai dengan permintaan pengguna. Menurut Sugiyono (2018:130) merupakan wilayah generelisasi yang terdiri atau obyek yang mempunyai kuantitas dan karakteristik tertentu yang ditetetapkan pada peneliti untuk dipelajari kemudian ditarik kesimpulannya. Menurut Nurdin \& Hartati (2019:91) Populasi merupakan keseluruhan subyek penelitian apabila seseorang hendak meneliti semua karakteristik 
dan elemen dalam suatu wilayah penelitian, tentu saja penelitian tersebut termasuk dalam penelitian populasi. Populasi penelitian di Taman Kanak-Kanak Bunga Harapan Bunga Pasang jumlah 24 orang. Adapun pengambilan sampel purposive jenuh menurut Wagiran (2013:199) sampling jenuh merupakan teknik penentuan sampel bila semua anggota populasi digunakan sebagai sampel penelitian. Sampel jenuh ini juga dikatakan sebagai sampel total ataupun sensus, yang mana populasi di sekolah tersebut dijadikan sampel mengisi koesonir yang telah peneliti siapkan.

Data yang sangat diperlukan yaitu teknik analisis data sesuai dengan pertanyaan. Setelah data di perolah akan di lanjtkan dengan mengolah data, tujuan agar dapat mengetahui kebenaran hipotesis dengan bantuan IBM SPSS 26.

Hasil dari penelitian ini berupa pengaruh pembelajaran bdr terhadap perkembangan sosial anak usia dini di Taman Kanak Bunga Harapan. Data yang diambil dari hasil penelitian, analisis angket yang diisi oleh orangtua, serta dokumentasi yang peneliti lakukan di Taman Kanak-Kanak Bunga Harapan Bunga Pasang. Data penelitian ini terdiri dari 2 variabel yaitu pembelajaran bdr (X) dan perkembangan sosial (Y). Deskripsi data ini mengungkapkan informasi tentang rata-rata, skor tengah, skor yang paling banyak muncul, simpangan baku, keragaman, rentangan, skor terendah, skor tertinggi dan jumlah skor. Dapat dilihat pada tabel 2.

\section{Tabel 2. Deskripsi Data Penelitian}

\section{Descriptive Statistics}

\begin{tabular}{lr|r|r|r|r|r} 
& N & Minimum & Maximum & \multicolumn{1}{c}{ Sum } & \multicolumn{1}{c}{ Mean } & Std. Deviation \\
\hline X & 24 & 6,00 & 11,00 & 200,00 & 8,3333 & 1,71100 \\
\hline Y & 24 & 5,00 & 12,00 & 203,00 & 8,4583 & 1,91059 \\
\hline Valid N (listwise) & 24 & & & & & \\
\hline
\end{tabular}

Dari data penelitian pembelajaran bdr dapat diketahui bahwa distribusi skor jawaban menyebar dari skor terendah 6.00 dan tertinggi 11.00. Dari distribusi skor tersebut didapatkan rata-rata (mean) sebesar 8,3333 dan simpangan baku (standar deviasi) 1,71100 selanjutnya 
perkembangan sosial skor terendah 5.00 dan skor tertinggi 12.00. Dari distribusi skor tersebut didapatkan rata-rata (mean) 8,4583 dan simpangan baku (standar deviasi) 1,91059.

Selanjutnya perhitungan uji normalitas dari kedua variabel $\mathrm{X}$ dan y dengan taraf $a 0,05$ untuk $N=24$ maka diperoleh signifikan $X$ dan $Y$ sebesar 200, dapat diketahui 200>0,05 maka dengan demikian dapat diambil kesimpulan bahwa data tersebut berdistribusi normal.

Untuk mengetahui uji linearitas maka nilai Fhitung $=1.326$, dan nilai sign (devation from linearity) $=0,319>a=0,05$, karena nilai signifikan lebih besar dari Alpah $(0,05)$ maka dapat dinyatakan bahwa variabel pembelajaran daring (x) terhadap perkembangan sosial (Y) dikategorikan linear.

Langkah selanjutnya pengujian hipotesis Pengujian hipotesis dalam penelitian ini menggunakan uji $\mathrm{T}$ dan uji $\mathrm{F}$ dengan bantuan IMB SPSS 26. Pada pengujian uji T dapat dilihat pada tabel 2 .

Tabel. 2. Uji T

\section{Coefficients $^{\mathrm{a}}$}

\begin{tabular}{|c|c|c|c|c|c|c|}
\hline & & & & \multirow{3}{*}{$\begin{array}{c}\text { Standardized } \\
\text { Coefficients } \\
\text { Beta } \\
\end{array}$} & \multirow[b]{3}{*}{$t$} & \multirow[b]{3}{*}{ Sig. } \\
\hline \multirow[b]{2}{*}{ Model } & & \multicolumn{2}{|c|}{ Unstandardized Coefficients } & & & \\
\hline & & B & Std. Error & & & \\
\hline \multirow[t]{2}{*}{1} & (Constant) & 4,085 & 1,786 & & 2,287 & ,032 \\
\hline & Pembelajaran_BDR &, 525 & ,210 & ,470 & 2,497 & ,020 \\
\hline
\end{tabular}

a. Dependent Variable: Perkembangan_sosial

Hasil perhitungan uji $\mathrm{T}$ dengan jumlah responden 24 orang, dengan uji 2 variabel maka dapat dilihat dari 2,497>1,711 maka dapat dinyatakan Ho ditolak dan Ha diterima. Artinya terdapat pengaruh yang signifikan antara pembelajaran bdr terhadap perkembangan sosial.

Hasil perhitungan Uji F dapat dilihat pada tabel 3 sebagai berikut:

Tabel 3. Uji F

\section{ANOVA $^{a}$}

Df 


\begin{tabular}{l|r|r|r|r|r}
\hline 1 & 18,541 & 1 & 18,541 & 6,235 &, $020^{5}$ \\
\hline Regression & 65,417 & 22 & 2,974 & & \\
\hline Total & 83,958 & 23 & & & \\
\hline
\end{tabular}

a. Dependent Variable: Perkembangan_sosial

b. Predictors: (Constant), Pembelajaran_BDR

Hasil perhitungan uji $\mathrm{F}$ terdapat pengaruh signifikan terhadap perkembangan sosial dibuktikan dengan $F_{\text {hitung }}>F_{\text {tabel }}$ atau 6,253>1,711 maka dapat dinyatakan Ho ditolak dan Ha diterima. Maka terdapat pengaruh yang signifikan antara pembelajaran bdr terhadap perkembangan sosial anak.

Berdasarkan perhitungan diatas dapat diketahui bahwa pembelajaran bdr dapat berpengaruh terhadap perkembangan sosial anak dapat dilihat dari pengujian hipotesis $\mathrm{T}_{\text {hitung }}>\mathrm{T}_{\text {tabel }}(2,497>1,711)$ dan $\mathrm{F}_{\text {hitung }}>\mathrm{F}_{\text {tabel }}(6,253>1,711)$ dengan perhitungan data menunjukkan pengaruh yang signifikan pada pembelajaran bdr terhadap perkembangan sosial anak di taman kanak-kanak bungan harapan bunga pasang.

\section{PEMBAHASAN}

Berdasarkan hasil penelitian di Taman Kanak-Kanak Bunga Harapan Bunga Pasang. Ditemukan pengaruh pembelajaran bdr terhadap perkembangan sosial anak. Hal ini terbukti bagaimana anak berperilaku dengan oranglain seperti anak yang kesulitan untuk berinteraksi dengan teman sebaya nya saat baru memasuki sekolah, serta anak yang tidak suka dengan keramaian dan lebih menyukai dirumah dari pada berbaur di lingkungan masyarakat.

Pada aspek perkembangan sosial mengacu pada proses belajar berinteraksi dengan orang lain disekitarnya. Kemampuan seorang anak untuk berinteraksi dengan orang-orang disekitarnya dapat mempengaruhi aspek-aspek perkembangan lainnya. Kemampuan tersebut harus dikembangkan sejak dini. Untuk membantu anak kelak untuk dapat berinteraksi dan mengambil perannya di masyarakat. Namun dengan saat ini anak yang belajar di rumah dan kurang berinteraksi dengan dunia luar akan membuat perkembangan sosial anak terhambat dapat dilihat 
dari hasil riset yang dilakukan pengujian hipotesis $T_{\text {hitung }}>T_{\text {tabel }}(2,497>1,711)$ dan $F_{\text {hitung }}>F_{\text {tabel }}$ $(6,253>1,711)$ yang artiny Ha dalam penelitian ini diterima yaitu terdapat pengaruh pembelajaran daring bdr terhadap perkembangan sosial anak, sedangkan hipotesis Ho ditolak.

\section{SIMPULAN DAN SARAN}

Berdasarkan hasil penelitian yag penulis uraikan pada bab sebelumya. Bahwa pembelajaran daring bdr terhadap perkembangan sosial di Taman Kanak-Kanak Bunga Harapan Bunga Pasang. Dari hasil uji hipotesis dapat diketahui bahwa pengujian hipotesis $T_{\text {hitung }}>T_{\text {tabel }}$ $(2,497>1,711)$. Kemudian dilanjutkan dengan $F_{\text {hitung }}>F_{\text {tabel }}(6,253>1,711)$ yang artinya Hipotesi Ha dalam penelitian ini diterima yaitu terdapat pengaruh pembelajaran bdr terhadap perkembangan sosial anak di Taman Kanak-Kanak Bunga Harapan Bunga Pasang, sedangkan Ho ditolak. Dengan demikian dapat disimpulkan bahwa pembelajaran daring bdr yang diselenggarakan tetap dapat membentuk perkembangan sosial anak usia dini di Taman KanakKanak Bunga Harapan. Berdasarkan hasil penelitian yang peneliti lakukan di Taman KanakKanak Bunga Harapan Bunga Pasang, maka peneliti memberikan saran-saran orangtua hendaknya memenuhi kebutuhan anak, dan tidak melarang anak untuk berteman dengan siapapun, guru hendaknya menggunakan strategi pembelajaran yang melibatkan setiap aspek-aspek perkembangan anak. untuk meningkatkan setiap perkembangan terutama perkembangan sosial agar anak dimasa depan nya mudah untuk berinteraksi dengan orang lain, bagi peneliti, hasil penelitian ini dapat menjadi sumber bacaan bagi peneliti lain untuk mengembangkan penelitian yang sama.

\section{DAFTAR PUSTAKA}

Kurniasari Arsila dkk. 2020. Analisis Efektivitas Pelaksanaan Belajar Dari Rumah (Bdr) Selama Pandemi Covid-19. (Vol 6 No 3 September 2020) Diunduh pada tanggal 11 Februari 2021 
Musyarofah. 2017. Pengembangan Aspek Sosial Emosional Anak Usia Dini Di Taman KanakKanak ABA IV Mangli Jember Tahun 2016. Jurnal Interdisciplinary Journal Of Communication (Vol 2 No 1 Juni 2017). Diunduh pada tangga 21 Januari 2021

Nurdin ismail \& hartati sri. 2019. Metodologi Penelitian Sosial. Surbaya: penerbit sahabat media cendikia

Ristyawati Aprista. 2020. Efektifitas Kebijakan Pembatasan Sosial Berskala Besar Dalam Masa Pandemi Corona Virus 2019 oleh Pemerintah Sesuai Amanat UUD NRI Tahun 1945 (Vol 2, No 2) Diunduh pada tanggal 19 April 2021

Sugiyono. 2013. Metode Penelitian Bisnis. Bandung: Alfabeta

Wagiran. 2013 . Metodologi Penelitian Pendidikan. Yogyakarta: cv budiutama

Suryana, Dadan. 2013. Pendidikan Anak Usia Dini. Padang: UNP Press

Suryana, Dadan. 2016. Pendidikan Anak Usia Dini. Stimulasi Dan Aspek Perkembangan Anak. Jakarta: Prenadamedia Group

Suryana, Dadan. 2021. Pendidikan Anak Usia Dini Teori dan Praktek Pembelajaran. Jakarta: Kencana

Yaswinda, Yulsyofriend \& Mayar F. 2018. Pengembangan Bahan Pembelajaran Sains Berbasis Multisensory Ekologi Bagi Guru Paud Kecamatan Tilantang Kamang Kabupaten Agam. Jurnal Pendidikan Anak Usia Dini (Vol 2, No 2) Diuduh pada tanggal 23 Februari 2021 